\title{
Histopathologic Analysis of Female Genital Tuberculosis: A Fifteen-Year Retrospective Study of 110 Cases in Eastern India
}

\author{
Kadın Genital Sistem Tüberkülozu: Hindistan'da 110 Olgunun \\ Retrospektif Histopatolojik Analizi
}

Santosh Kumar Mondal

Department of Pathology, Medical College, KOLKATA, INDIA

\begin{abstract}
Objective: Tuberculosis remains a global health problem and is an important cause of morbidity and mortality. Female genital tuberculosis is rare in the western world, but relevant in developing countries like India. The aim of this study was to determine histologic findings of different parts of the female genital tract affected by tuberculosis and to correlate it with other features.
\end{abstract}

Material and Method: A total number of 110 cases of female genital tuberculosis from 92 patients were included over a period of 15 years. The age range of the patients was 17 to 45 years with a mean of 26.3 . The diagnostic procedures used were curettage biopsy, hysterectomy, histologic examination, culture, Mycobacterium Tuberculosispolymerase chain reaction, laparoscopy, hysterosalpingography and ultrasonography.

Results: Patients with female genital tuberculosis presented with infertility (65-70\%), pelvic/ abdominal pain (50-55\%) and menstrual disturbances (20-25\%). Female genital tuberculosis involved the vulva (2), vagina (1), cervix (5), endometrium (66), fallopian tube (24) and ovaries (12). Out of 66 endometrial tuberculosis cases, proliferative, secretory endometrium and atrophic endometrium were seen in 53 , 9 , and 4 cases, respectively. HIV co-infection was found only in 5 cases and acid-fast bacilli in tissue sections were detected in 7 cases.

Conclusion: Female genital tuberculosis is not uncommon in developing countries and is an important cause of infertility. Though the fallopian tube was the most common site in many studies, the endometrium was the commonest site in this study.

Key Words: Tuberculosis, Female genital, Histopathology, HIV

\section{ÖZ}

Amaç: Tüberküloz evrensel bir sağlık sorunudur ve önemli mortalite ve morbidite nedenidir. Batı dünyasında nadir olmakla birlikte kadın genital sistemi tüberkülozu Hindistan gibi gelişmekte olan ülkelerde gündemdedir. Bu çalışmada, kadın genital sistemi tüberkülozunun histolojik özellikleri ve diğer bulgular ile ilişkisi araştırılmaktadır.

Gereç ve Yöntem: Onbeş y1llık dönemde tanı konan toplam 92 olguda 110 kadın genital sistemi tüberkülozu çalışmaya alınmıştır. Olguların yaşları 17-45 arasında değişmekteydi ve ortalama yaş 26,3 olarak gözlendi. Tanıda küretaj biyopsi, histerektomi, histolojik inceleme, kültür, Mycobacterium tuberculosis - Polimeraz Zincir Reaksiyonu, laparoskopi, histerosalpingografi ve ultrasonografi kullanılmıştı.

Bulgular: Kadın genital sistemi tüberkülozu olguları infertilite (\%6570), pelvik/ abdominal ağrı (\%50-55) ve menstrual yakınmalarla (\%20-25) başvurmuşlardı. Kadın genital sistemi tüberkülozu vulva (2), vajina (1), serviks (5), endometrium (66), tuba (24) ve ovaryumları (12) tutmuştu. Olguların 66'sında endometrium tüberkülozu yanısıra proliferatif, sekretuvar ve atrofik endometrium gözlendi (s1rasiyla 53, 9, 4 olgu). Sadece 5 olguda HIV ko-enfeksiyonu gözlendi. Olguların 7'sinde doku kesitlerinde asit fast basil saptand.

Sonuç: Kadın genital sistemi tüberkülozu gelişmekte olan ülkelerde nadir değildir ve infertilitenin önemli bir nedenidir. Çoğu çalışmada tubular en sık tutulan organ olmasına karşılık, çalışmamızda endometrium en sık tutulan organ olarak dikkati çekmektedir.

Anahtar Sözcükler: Tüberküloz, Kadın genital, Histopatoloji, HIV

\section{INTRODUCTION}

Morgagni first described genital tuberculosis in the mid eighteenth century and the tuberculous bacillus was discovered in 1882 by Koch (1). Tuberculosis is the

(Turk Patoloji Derg 2013, 29:41-45)

Received : 28.05.2012 Accepted : 11.09.2012 second most common cause of death worldwide amongst communicable diseases. It kills nearly 2 million people each year and developing countries are mostly affected (2). Genital tuberculosis in females occurs secondary to
Correspondence: Santosh Kumar Mondal

Department of Pathology, Medical College, KOLKATA, INDIA

E-mail: dr_santoshkumar@hotmail.com Phone:+91 3325472231 
primary disease in the lung, lymph nodes, urinary tract, bones, joints, and bowel. The spread is usually by the hematogenous or lymphatic route. Sexual transmission of female genital tuberculosis (FGTB) has been reported but direct spread from other intraperitoneal foci is very rare.

The exact incidence of FGTB cannot be determined with certainty as some cases are asymptomatic and detected incidentally during investigation of infertility. In developing countries, FGTB accounts for $\geq 3 \%$ of patients with infertility (1).

\section{MATERIAL and METHODS}

A retrospective study on FGTB was done over a period of 15 years in our institute from April, 1997 to March, 2012. Detailed clinical information, radiologic and other relevant investigations were recorded from case sheets. The clinical information included age of the patients, signs and symptoms, socio-economic background, presence of tuberculosis (lung/non-genital) and HIV in the patient and family. Radiologic investigations included chest X-ray, ultrasonography (USG) of abdomen/pelvis, hysterosalpingography (HSG) and computed tomography scan. Information regarding other relevant investigations like Mantoux test/Purified Protein Derivative (PPD) skin tests, erythrocyte sedimentation rate etc. were also recorded.

Histologic examination of tissue biopsies was done in the pathology department and reports were collected. Slides were stained by Hematoxylin and Eosin and Ziehl-Neelsen $(\mathrm{ZN})$ routinely. Periodic Acid Schiff and other special stains like Gomori's methanamine silver stain were done whenever necessary to exclude fungal etiology. Microbiological culture was done in all cases and Mycobacterium Tuberculosis Polymerase Chain Reaction (MTB-PCR) was done in 72 cases.

A total of 110 cases of FGTB were retrieved during this 15 years period from 92 patients. The age range of the patients was $17-45$ years; with a median age of 26.3 years. Most common specimens in this study were endometrial curettage and biopsy (61 cases) for evaluation of infertility, followed by tubo-ovarian mass and hysterectomy. In 8 cases, specimens of total hysterectomy with bilateral salpingoophorectomy were submitted with lesions involving multiple sites.

Diagnosis of FGTB was established by epithelioid granulomas in histopathologic examination (which was a must) and positivity by PCR, culture, PPD, HSG, laparoscopy, USG, etc. and clinical features. Rather than depending on a single diagnostic test, we preferred to combine all diagnostic tests together along with clinical corroboration and presence of epithelioid granulomas for making a diagnosis of FGTB. Mycobacterial culture was done on Lowenstein Jensen medium/BACTEC culture and for MTB-PCR; we looked for positive band of $123 \mathrm{bp} \mathrm{DNA}$ fragment of IS 6110 gene of M. Tuberculosis.

\section{RESULTS}

During the fifteen-year study period, we received 110 cases of FGTB, of which tuberculosis of the endometrium made up 66 cases, fallopian tube 24 cases, ovary 12 cases, cervix 5 cases, vulva 2 cases, and vagina 1 case (Table I).

Table I: Tuberculosis of different anatomical sites and percentage

\begin{tabular}{|l|c|c|c|c|}
\hline Site & Number (\%) & HIV Co-Infection & Caseation Present & AFB Present In Tissue Section (ZN Stain) \\
\hline Vulva & $2(1.81)$ & - & - & - \\
\hline Vagina & $1(0.91)$ & - & - & - \\
\hline Cervix & $5(4.54)$ & - & - & 2 \\
\hline Endometrium & $66(60)$ & 3 & 2 & - \\
\hline Proliferative & $53(48.18)$ & - & - & - \\
\hline Secretory & $09(8.18)$ & - & - & - \\
\hline Atrophic & $04(3.64)$ & - & - & 4 \\
\hline Fallopian tube & $24(21.82)$ & 1 & 9 & - \\
\hline Bilateral & $18(16.36)$ & - & - & - \\
\hline Unilateral & $06(5.45)$ & - & - & - \\
\hline Ovaries & $12(10.91)$ & 1 & 3 & - \\
\hline Bilateral & $07(6.36)$ & - & - & 7 \\
\hline Unilateral & $05(4.54)$ & - & - & \\
\hline Total & $110(100)$ & 5 & 14 & \\
\hline
\end{tabular}


Most of these patients affected by FGTB were poor with low education (78 patients). Twelve patients were from the middle income group, whereas only two patients came from affluent families. Most of the endometrial tuberculosis cases were in the proliferative phase (53/66), followed by the secretory phase $(9 / 66)$ and atrophic endometrium $(4 / 66)$. Bilateral involvement was seen in 18 out of 24 cases of fallopian tube tuberculosis and in 7 out of 12 cases of ovarian tuberculosis. HIV co-infection was seen in 5 cases and caseation was found in 16 cases. Acid-fast bacilli (AFB) in tissue section were detected in 7 cases.

All the five patients with HIV co-infection presented with weight loss and fever. Three of them had generalised lymphadenopathy and one had pulmonary fungal infection (candidiasis). Among the 110 cases of FGTB, positivity for PCR, culture and PPD test were present in 41 cases (37.3\%), 9 cases (8.2\%) and 45 cases (40.9\%), respectively.

The main histologic finding in endometrial tuberculosis was the presence of epithelioid cell granulomas in different stages. Most of these granulomas were small to medium sized, isolated and scattered through the functionalis layer (Figure 1). Confluent granulomas were not detected in endometrial tuberculosis. Multinucleated giant cells of both Langhans and foreign body type were present in some cases (11/66), and disruption of endometrial glands was seen in 3 cases. Plasma cells were found in 5 cases, where secondary infection was also present. Caseation was rarely found in endometrial tuberculosis (2/66), and both of these patients were post-menopausal. AFB were also rarely detected (2/66) (Figure 2).

Fallopian tubes involved by tuberculosis appeared to be enlarged and slightly oedematous grossly (23/24). The external surface was irregular due to adhesions (17/24). In five cases, the fimbria were everted with a patent orifice, imparting a characteristic "tobacco pouch" appearance. On cut surface, serosanguinous fluid was found in 9 cases, blood in 2 cases, caseous material in five cases, clear fluid / hydrosalpinx in 5 cases and pus in 3 cases. Diffuse or focal mucosal ulceration were noted in most of the cases $(21 / 24)$. Microscopically, the features were of chronic salpingitis with occasional non-caseating granulomas in early stage (7/24). Plical adhesion with follicular salpingitis was seen in the early stage (Figure 3$)$. In the late advanced stage (17/24), single and/or multiple confluent epitheloid granulomas were present in the lamina propria. Involvement of the muscularis layer $(4 / 24)$ and serosa $(2 / 24)$ were seen occasionally. Caseation (9/24) and AFB in tissue sections $(4 / 24)$ were found in a fair number of cases.

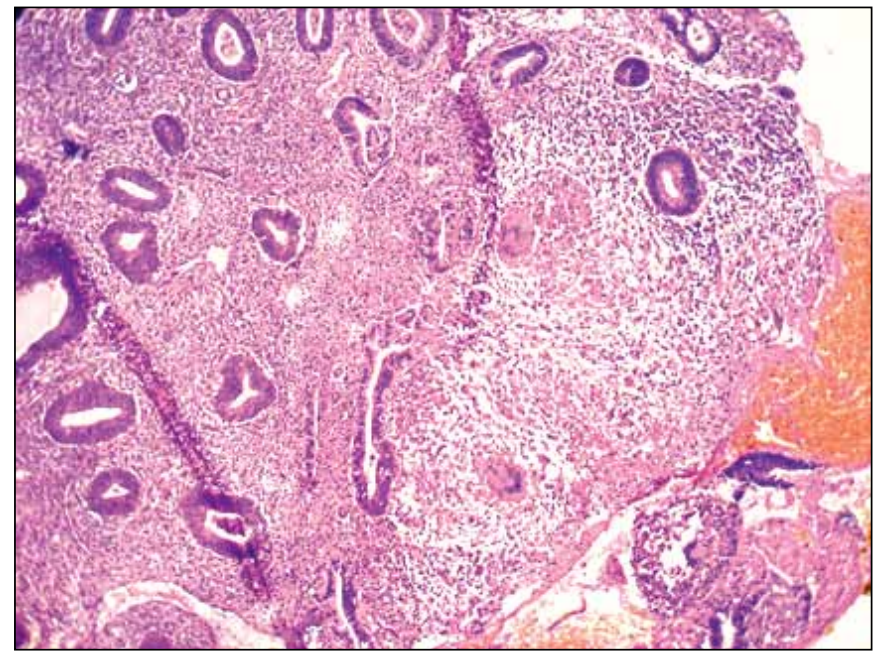

Figure 1: Photomicrograph showing epithelioid granulomas of tuberculosis in the proliferative endometrium. Both Langhans and foreign body type of giant cells are also present (H\&E, x10).

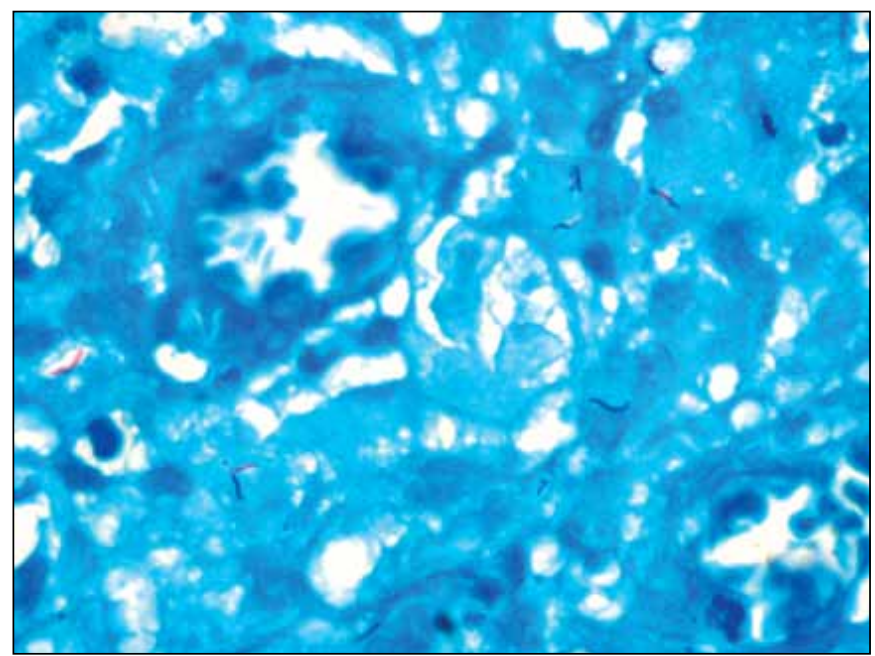

Figure 2: Zeihl-Neelsen stain showing bacilli of tuberculous mycobacterium in the same endometrium (x100).

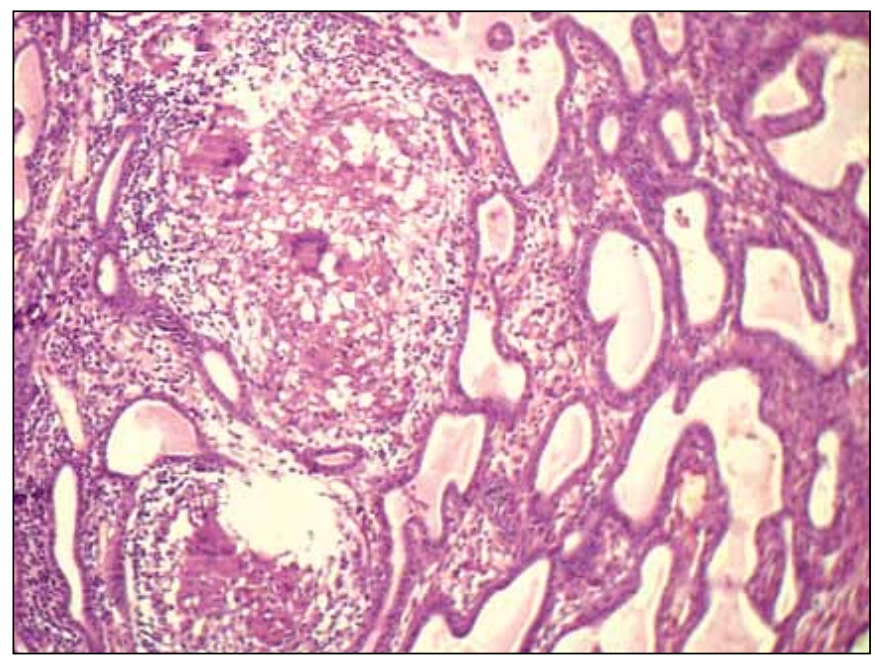

Figure 3: Photomicrograph showing tuberculous granulomas in the mucosal layer of fallopian tube and fused plica (H\&E, x10). 


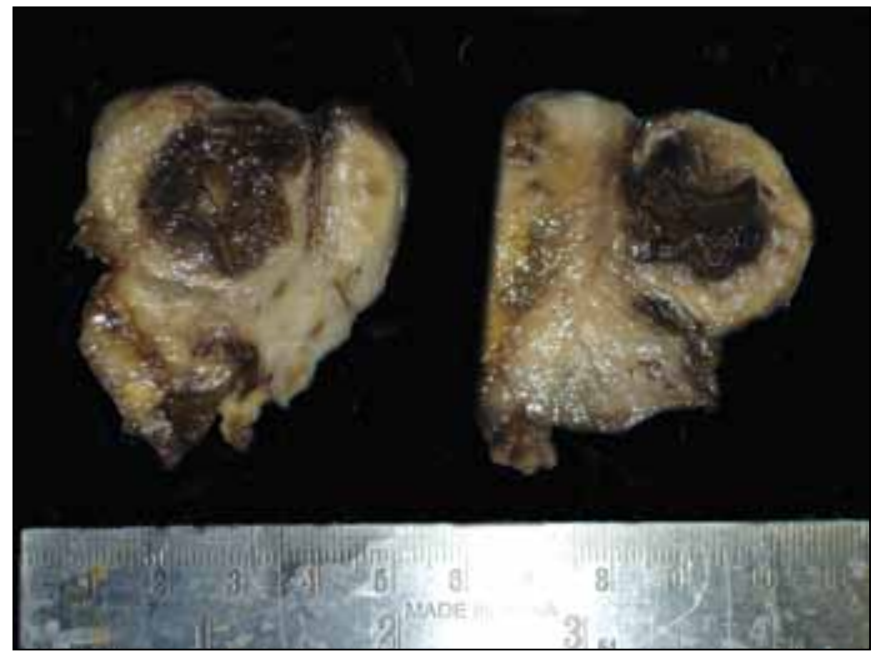

Figure 4: Gross photograph showing tubo-ovarian mass which was the presenting feature in a case of ovarian tuberculosis.

Ovarian tuberculosis presented as tubo-ovarian mass and usually a sequel of tuberculous salpingitis (Figure 4). The granulomas were seen in the cortical area in the majority of cases (3/12). Caseation was seen in three cases, of which one showed AFB in tissue sections.

Cervical tuberculosis grossly appeared as red, enlarged, ulcerated and friable with clinical misdiagnosis of cervical cancer in three cases. The commonest site of involvement was the mucosa of the endocervical canal. As in other sites, epithelioid granulomas were present but caseation was absent in all five cases. The vulva (2 cases) and vagina (1 case) were rarely involved and caseation and AFB were absent as in cervical tuberculosis.

A clinical suspicion of FGTB was present in 85 cases. The diagnosis was established only by MTB-PCR in 5 cases (where other tests were negative) and in the remaining 105 cases by multiple ancillary tests.

\section{DISCUSSION}

Most cases of tuberculosis (95\%) occur in developing countries. However, the prevalence of tuberculosis in developed countries has recently increased due to HIV infection, immigration and the development of drugresistant stains of Mycobacterium tuberculosis (3). Patients suffering from latent tuberculosis are more prone to have active tuberculosis if co-infected with HIV (20 times more risk than HIV-negative patients). HIV infection also causes recent tuberculous infection as well (4). In our study, 5 cases of HIV co-infection were present amongst 110 cases of FGTB (4.5\%). According to a current report, nearly 5.1 million people in India are HIV-positive and $60 \%$ of these patients also have tuberculosis (5).
FGTB patients are usually in the reproductive age group. The most common presentation findings reported were infertility (44\%), pelvic pain (25\%), vaginal bleeding (18\%), amenorrhoea (5\%), vaginal discharge (4\%), and postmenopausal bleeding $(2 \%)(6,7)$. Less common presentations were ascites, abdominal mass, tubo-ovarian abscess and vague abdominal distention (7). In our study, three common presentations were infertility (65-70\%), pelvic abdominal pain (50-55\%), and menstrual disturbances (20-25\%). In most of the studies, the fallopian tubes were affected in $100 \%$ of the cases followed by the endometrium (50\%), ovaries $(20 \%)$, cervix $(5 \%)$, and vulva and vagina $(<1 \%)(4,8)$. However, the endometrium was the most common site in our study (60\%), followed by the fallopian tube $(21.82 \%)$, ovaries $(10.9 \%)$, cervix $(4.54 \%)$, vulva $(1.81 \%)$, and vagina (0.91\%).

The higher incidence of endometrial tuberculosis in our study might be explained by the fact that most of the specimens we received were endometrial curettage specimens during work-up of infertile women. When tuberculosis affects the female genital tract, the fallopian tube is involved in almost all cases and endometrial involvement is usually secondary to tubal disease. However, the number of endometrial tuberculosis cases (66) is higher than fallopian tube disease cases (24) in the present study. This might be due to sample bias, as most specimens we received were endometrial biopsies for diagnostic work-up in infertile women.

During the reproductive period, caseation is rare in tuberculous endometritis (9). However in postmenopausal women, tuberculous granulomas have enough time to develop caseation as there is no periodic loss of endometrium to menstruation. In our study also both the patients with tuberculous endometritis with caseation were postmenopausal. In the reproductive age, tuberculous granulomas have to regenerate from the basal layer after menstrual shedding of the functionalis layer. The granulomas become well developed and numerous as the menstrual cycle progresses. Biopsy is therefore recommended just before menstruation or the late secretory phase, as the granulomas get the longest possible time to develop and there is a greater chance of providing an accurate diagnosis. In most of the studies, endometrial tuberculosis occurs mainly in women of the reproductive age group, but Falk $\mathrm{V}$ et al. found most cases in the postmenopausal group (10). Genital tuberculosis is rare in postmenopausal women and comprises $1 \%$ of postmenopausal bleeding cases (11). The exact cause of the low incidence of the disease in this age group is not known. Most authors believe that an atrophic endometrium is a 
poor milieu for the growth of Mycobacterium tuberculosis bacilli (12).

Pelvic tuberculosis may mimic ovarian malignancy and CA-125 may be falsely elevated $(13,14)$. After successful treatment of tuberculosis, CA-125 returned to normal levels. FGTB usually occurs as a result of seeding of bacilli immediately after puberty as blood supply to the pelvic organ increases. As a result, more bacilli can reach these organs and infect them (15). Primary infection may also occur if the male partner has active genito-urinary tuberculosis and transmission may occur through sexual intercourse. Infection of vulva, vagina and cervix may result from direct inoculation and ascending infection to other genital organs $(15,16)$. In most of the series of FGTB, the vulva and vagina are uncommon sites of infection (17). In our study also, the incidence of vulvar and vaginal tuberculosis was $1.81 \%$ and $0.91 \%$, respectively.

The diagnosis of FGTB is challenging as it is rarely pinpointed by clinical symptoms because of their low specificity. Elaborate examination (pelvic ultrasound, chest $\mathrm{x}$-rays, bacteriological culture, ZN stain, PCR analysis, histopathologic examination) should be carried out for accurate diagnosis. Microscopic examination of AFB on $\mathrm{ZN}$ stain requires the presence of at least $10^{4}$ organisms $/ \mathrm{ml}$ in the sample whereas culture is more sensitive, requiring as little as $10^{2}$ organisms $/ \mathrm{ml}$ (18). Recently, PCR has emerged as a rapid, sensitive and specific molecular method to diagnose female genital TB with a turnaround time of 1-2 days (19).

There are scant prospective data regarding optimal management of FGTB. In our patients, anti-TB drugs which included isoniazid, rifampicin, pyrazinamide and ethambutol were given for a two-month period and the first two agents for an additional four months (20).

Surgical therapy usually consists of total abdominal hysterectomy and salpingo-oophorectomy. Persistence of pelvic mass and recurrence of pain or bleeding after 9 months of medical treatment are indications for surgical intervention. Surgery should be attempted at least 6 weeks after initiation of anti-tuberculosis regimen, as antimicrobial treatment facilitates the surgical procedure and reduces the risk of perioperative complications (21).

\section{REFERENCES}

1. Chow TW, Lim BK, Vallipuram S: The masquerades of female pelvic tuberculosis: Case reports and review of literature on clinical presentations and diognasis.J Obstet Gynaecol Res 2002, 28:203-210
2. World Health Organisation: Global tuberculosis control: Survillance, planning, financing. WHO report, 2007. Geneva, 2007

3. Muttarak M,ChingMai W N, Lojanpiwat B: Tuberculosis of the genitourinary tract: Image features with pathological correlation. Singapore Med J 2005, 46:568-574

4. Antonucci G, Girardi E, Raviglione MC, Ippolito G: Risk factors for tuberculosis in HIV- infected persons: A prospective cohort study. JAMA 1995, 274:143-148

5. Government of India: Annual Report 2005-06.Ministry of Health and Family Welfare. New Delhi, 2006

6. Samal S, Gupta U, Agarwal P: Menstrual disorders in genital tuberculosis. J Indian Med Assoc 2000, 98:126-127

7. Carter JR: Unusual presentation of genital tract tuberculosis. Int J Gynecol Obstet 1990, 33:171-176

8. Nogales-Ortiz F, Tarancón I, Nogales FF Jr: The pathology of female genital tuberculosis: A 31 year study of 1436 cases. Obstet Gynecol 1979, 53:422-428

9. Roy A, Mukherjee S, Bhattacharya S, Adhya S, Chakraborty $P$ : Tuberculous Endometritis in hills of Derjeeling: A clinicopathological and bacteriological study. Indian J Pathol Microbiol 1993, 36:361-369

10. Falk V, Ludviksson K, Agren G: Genital tuberculosis in women. Analysis of 187 newly diagnosed cases from 47 Swedish hospitals during the ten year period 1968 to1977. Am J Obstet Gynecol 1980, 138:974-977

11. Gungorduk K, Ulker V, Sahbaz A, Ark C, Tekirdag AI: Post menopausal tuberculous endometritis. Infect Dis Obstet Gynecol 2007, 2007:27028. Epub 2007 May 8

12. Maestre MAM, Manzano CD, Lopez RM: Postmenopausal endometrial tuberculosis. Int J Gynecol Obstet 2004, 86:405-406

13. Kawatra V, Kohli K, Khurana N: Pelvic tuberculosis mimicking ovarian malignancy: A case report. J Reprod Med 2010, 55: 449-451

14. Bilgin T, Karabay A, Dolar E, Develioglu OH: Peritoneal tuberculosis with pelvic abdominal mass, ascites and elevated CA125 mimicking advanced ovarian carcinoma: A series of 10 cases. Int J Gynecol Cancer 2001, 11:290-294

15. Duggal S, Duggal N, Hans C, Mahajan RK: Female genital TB and HIV co-infection. Indian J Med Microbiol 2009, 27:361-372

16. Hass DW: Mycobacterial disease. In: Mandell GL, Bennet JE, Dolin R, Eds): Principles and practice of infectious disease. Philadelphia, PA, Churchil Livingstone, 2000, 2576-2607

17. Buppasiri P, Temtanakitpaisan T, Somboonporn W: Tuberculosis at vulva and vagina. J Med Assoc Thai 2010, 93:613-615

18. Bates JH: Diagnosis of tuberculosis. Chest 1979, 76 (6 Suppl): 757-763

19. Bhanu NV, Singh UB, Chakraborty M, Suresh N, Arora J, Rana T, Takkar D, Seth P: Improved diagnostic value of PCR in the diagnosis of female genital tuberculosis leading to infertility. J Med Microbiol 2005, 54:927-931

20. Onyebujoh PC, Ribeiro I, Whalen CC: Treatment options for HIV-associated tuberculosis. J Infect Dis 2007, 196:35-45

21. Sutherland AM: Surgical treatment of tuberculosis of the female genital tract. Br J Obstet Gynecol 1980, 87:610-612 